\title{
Polysèmes
}

Revue d'études intertextuelles et intermédiales

\section{From Parodies of the Iron Lady to Margaret Thatcher's Political Image}

Des parodies de la Dame de fer à l'image politique de Margaret Thatcher

Yves Golder

\section{(2) OpenEdition \\ 12 Journals}

\section{Electronic version}

URL: http://journals.openedition.org/polysemes/7606

DOI: $10.4000 /$ polysemes.7606

ISSN: 2496-4212

Publisher

SAIT

\section{Electronic reference}

Yves Golder, "From Parodies of the Iron Lady to Margaret Thatcher's Political Image », Polysèmes [Online], 23 | 2020, Online since 30 June 2020, connection on 10 December 2020. URL: http:// journals.openedition.org/polysemes/7606; DOI : https://doi.org/10.4000/polysemes.7606

This text was automatically generated on 10 December 2020 .

Polysèmes 


\title{
From Parodies of the Iron Lady to Margaret Thatcher's Political Image
}

\author{
Des parodies de la Dame de fer à l'image politique de Margaret Thatcher
}

Yves Golder

\section{Introduction}

In 1974, one year before she became leader of the British Conservative Party, Margaret Thatcher made the following statement: "It will be years-and not in my time-before a woman will lead the party to become Prime Minister" (Blake and John 140). It seemed impossible for a woman born in 1925, who started to campaign for an election in 1950, to become a political party leader; it seemed even more unrealistic to think of her becoming head of government. However, in 1979, she became Prime Minister of the United Kingdom, as leader of the Conservatives, when her party won the general election. This article focuses on Margaret Thatcher's gender as a woman while taking into account the ways in which her womanhood was parodied, essentially by male journalists and caricaturists. It will rely on the tools generally used to analyse literary works while adapting them to the study of a central twentieth-century political figure. Parody involves imitation and satire as it implies both a representation and a distortion of reality. Indeed, it reactivates realities but also involves a creative dimension. In their imitations, parodists often exaggerate certain features for comic effect. As Georges Minois wrote, the late twentieth century was a period of time when, thanks to the support of communication advisers, the political sphere started to use comedy in order to exert more influence (550). Satire may have lost its power to desacralize politicians as politicians themselves have started to use it to appear more attractive. The media have, to a great extent, participated in the circulation of these parodies and this article presents some of the parodies which concern Margaret Thatcher, a focal target in late twentieth-century Britain. As one of her biographers, Eric Evans, wrote: "Margaret Thatcher, no less than Grace Kelly or Katharine Hepburn, was a star" (93). This accounts for the innumerable parodies of Margaret Thatcher which were produced. 
Indeed, as soon as her political involvement started, she became the centre of attention of the media as well as of British artists, film producers and novelists, and she took advantage of that situation to promote herself and her ideas. If she was such an impressive and interesting personality, it was essentially because she was a powerful woman, the first female Prime Minister in a Western country. Indeed, as her biographer John Campbell put it: "Male tyrants are simply loathed, but a powerful woman attracts fascinated attention from both sexes" (Campbell 2003, 472). The fact that Margaret Thatcher was able to draw such attention did not prevent the harsh criticism that was directed against her. That said, she was not only an object of satire: she devised her own counterattacks in order to improve her self-presentation by constantly updating and improving her political image. What was the role played by gender in both processes of satire and retaliation? How was gender used to ridicule her and/or strengthen her authority?

2 The first part of this article will be devoted to the parodies based on the representations of Margaret Thatcher as either feminized or masculinized. The second part will explore the way parodies depicted Margaret Thatcher as a desexualized, ungendered politician, that is to say a politician deprived of her real identity. Eventually, the focus will be on Margaret Thatcher's attempts at rebuilding her political image in order to benefit from a positive reputation. The final section will therefore show that Thatcher deliberately exaggerated characteristics commonly associated with femininity and masculinity for the sake of her own political image.

3 In order to examine these different points, this paper will first use extracts from Margaret Thatcher's speeches when she was in power as Prime Minister. Then, a corpus of different media-cartoons, posters and TV broadcasts-, all dating from the same period and all having a parodic or satiric dimension, will be studied.

\section{Margaret Thatcher parodied: from femininity to masculinity}

4 As a woman politician who achieved her ambitions by becoming Prime Minister of the United Kingdom, Margaret Thatcher was often parodied on the basis of her gender. As Judith Butler wrote in Gender Trouble, "it [is] impossible to separate out 'gender' from the cultural intersections in which it is invariably produced and maintained" (5). Therefore, we can assume that Margaret Thatcher might have been perceived as a rather feminine or masculine personality even though, in terms of sex, it is obvious that she was a woman. Hence parodists tried to show that the British politician exhibited various characteristics which are stereotypically associated with the conflicting notions of femininity and masculinity.

Most of the parodies of Margaret Thatcher exaggerated her feminine characteristics. Thus the parodies of this female politician were quite revolutionary because male politicians could not be portrayed in the same way as she was. A good example of this representation is the parody of the poster for the movie Gone with the Wind by Bob Light and John Houston (1981). According to Bob Light, "it was designed [in December 1980] for the Christmas edition of the Socialist Worker" newspaper and it was reprinted as a poster in early $1981 .{ }^{1}$ At that time, it denounced the negative consequences of Margaret Thatcher's economic policies. Indeed, two years after the start of her first prime- 
ministerial mandate, her popularity kept on decreasing as unemployment kept risingfrom $5,8 \%$ in 1979 to nearly $10 \%$ in $1981^{2}$-and because, even though she had imposed tough economic measures, she did not manage to curb inflation-which peaked at $18 \%$ in $1980^{3}$-in the short term. Moreover, Bob Light, who was a trade unionist, was against her decision to attack the British trade unions. That said, the main objective of this parody was to criticise the strong partnership which was developing between the British Prime Minister and the American President, Ronald Reagan. On this parodic poster, Ronald Reagan is holding his British counterpart in his arms and the caption promotes "the most EXPLOSIVE love story ever". The adjective "EXPLOSIVE" appears in capital letters as it puts forward the negative impact of the so-called "special relationship" and its neoliberal dogma, not only on British and American people but on people from all over the world. According to Bob Light, the faces of Mrs. Thatcher and Mr. Reagan were cut from a picture published in the Daily Mail and pasted on the real Gone with the Wind poster. At the top of the poster, there is a short caption announcing "the film to end all films" as if the neoliberal policies promoted in the context of the "special relationship" could destroy and put an end to humanity, while the reference to "Milton Friedman" corresponds to an allusion to the father of monetarism, the economic foundation of the New Right's neoliberal policies. This caption is also likely to be a reference to the escalation of tensions in the context of the cold war when Britain hosted American cruise missiles on its army bases at the Greenham Commons base for instance.

6 As far as the postures of both Margaret Thatcher and Ronald Reagan are concerned, it appears that the American President is holding the British Prime Minister in his arms as if he had been seduced by her smiling appearance. While this scene takes place in the foreground, there is an explosion reminiscent of the threat posed by nuclear weapons in the background. The two politicians, parodied as lovers, do not seem to pay any attention to this explosion which highlights their indifference to the suffering of other people, often parodied as a form of cruelty. Under the picture, there is a comment providing information on the plot of the "special relationship", as if it were part of a movie: "She promised to follow him to the end of the earth. He promised to organise it!" The verb "to promise" is generally used in the context of a wedding vow, but beyond the bilateral contract presented here lies a representation of the woman figure as a passive agent whereas the man is represented playing an active role in the relationship. This kind of parody therefore exploited sexist clichés, also implying that Britain was the puppet of the Americans and that the "special relationship" was all but a relationship of equals, Britain sheepishly following the US on its destructive path. At the very bottom of the poster, the caption "Now showing worldwide" indicates the international repercussions of the "special relationship" as if the danger was not only for Britain or the United States. Indeed, the two leaders put worldwide peace in jeopardy. The early 1980s corresponded to a period of mounting tensions between the Western and Eastern blocks. The threat of nuclear warfare was on everybody's mind, hence the picture's title "Gone with the Wind" which is a double entendre alluding to total destruction due to nuclear weapons.

7 In spite of the women's liberation movement in the 1960s, many sexist representations of Margaret Thatcher continued to be produced until 1990. For instance, she was often compared to a dull housewife even though these parodies could sometimes have a positive inflection as in this extract from the Daily Mirror dating from February $3^{\text {rd }}$ 1975: "Margaret Thatcher had all her chores neatly lined up at the weekend. First there was 
the kitchen to tidy. Then the bathroom, a dash around with a duster and on to the shopping and the laundry. And after that she had to tidy up the Tory party, polish off Ted Heath and give Britain a good spring cleaning" (Campbell 2000, 297). This quotation provides a good example of the way Margaret Thatcher's housewifely qualities were sometimes parodied precisely because she was a successful woman who could perform all the necessary domestic tasks while managing the affairs of a great nation efficiently. In this quotation, her domestic qualities are presented as assets enabling her to skilfully rule her country. She was therefore comparable to the perfect housewife of Shirley Conran's Superwoman, a guide addressed to British housewives published in 1975. That said, this quotation can also be considered as a way of mocking Margaret Thatcher's attempt at juxtaposing home affairs and political responsibilities, as if both domains were similar and therefore comparable.

Parodies of Margaret Thatcher's femininity also portrayed her as a sadistic or cruel woman. As sadomasochistic relationships correspond to a reversal of social conventions, it is often the woman who plays the sadistic role. In the 1980s in particular, several parodists portrayed Margaret Thatcher as an authoritarian woman, often as a cruel nanny or schoolmistress. For instance, in the TV show Spitting Image, broadcast in the United Kingdom from 1984 to 1996, she was often parodied as a schoolmistress hectoring the members of her Cabinet as if they were pupils. In the third episode of the first season, she keeps rebuking them because they are entertaining themselves and cannot stop playing with anything they can find on the table of the Cabinet room. ${ }^{4}$ This parody was quite effective for, in the late 1980s, many British people watched the series mainly because their Prime Minister was the main character in the show.

9 When, in the 1980s, the French President, François Mitterrand, met his British counterpart, he was reported to have quickly devised a parodic expression which highlighted the fact that she could be both very feminine and extremely masculine in her attitude. The expression "elle a les yeux de Caligula et la bouche de Marilyn Monroe" can be translated into English as "she has the eyes of Caligula and the mouth of Marilyn Monroe". This strange mixture sums up the idea that she could be as tough and belligerent as the Roman Emperor Caligula and as sweet and glamourous as the American actress Marilyn Monroe. Parodying her as either feminine or masculine was a way of exposing the contradictions at the heart of her political image. As this quotation was reported from a private interview given by François Mitterrand, it is difficult to know the exact words he used. Some commentators have claimed that the French President actually said "elle a les yeux de Staline" / "she has the eyes of Stalin" instead of those of Caligula. Among these commentators, there was a member of Mr. Mitterrand's government, Jacques Attali. Even though Mr. Attali defended this second version of the quotation, the reference to the Roman Emperor appears much more often than the reference to the USSR leader in contemporary accounts. ${ }^{6}$ Whichever the original quotation was, it is clear in this statement that François Mitterrand wanted to insist on the mixture of toughness and seductiveness in Margaret Thatcher's attitude. She was a difficult leader to deal with for many of her counterparts indeed.

10 Therefore, besides being parodied as a feminine woman, Margaret Thatcher was often portrayed as a masculine figure. Whether they aimed at giving a positive or negative inflection to her reputation, these parodies generally insisted on the stereotypes of 
toughness, determination and sometimes brutality. For example, an article published by the Daily Express on June $9^{\text {th }} 1983$-the day of the general elections-was entitled "Now Is the Hour-Maggie Is the Man" (Filby 141). After four years of her premiership, this statement reaffirmed her capacity to overcome state socialism. ${ }^{7}$ Moreover, this title probably aimed at highlighting the unity which prevailed in the ranks of the Conservative Party whereas the Labour Party was at that time characterised by an atmosphere of disunity and chaos. Many organs of the press attacked its leader, Michael Foot, for being responsible for such a lack of cohesion. Margaret Thatcher was therefore often represented as a strong leader as opposed to Michael Foot who was portrayed as much weaker. This contrast between the two politicians was often exaggerated as it was easy to develop on the extreme divergences which opposed them.

11 Besides, in Spitting Image, the puppet representing the British Prime Minister was sometimes shown wearing a suit and tie, and holding a cigar. This representation constituted a reference to one of her famous predecessors, Winston Churchill. In this context, parodying her as a male figure, and especially one considered as a hero of the Second World War, enabled the producers of the TV show to insist on the stereotypical idea according to which men are strong in the face of adversity and ready to fight to defend themselves. Moreover, at that time, there might have been a sense that only men could be strong rulers and that her masterfulness made her abnormally masculine. In this respect, we can also note that caricaturists like Nicholas Garland claimed that they started to represent her "more strong [and] vigorous" (Moore 2015, 640) after the 1982 Falklands War than they had done before. This war, which was triggered by the Argentine invasion of the Falkland Islands, gave Margaret Thatcher the possibility to express the stereotypical qualities of a warrior.

12 Finally, in a trivial and comic way, a satire elaborated by Spitting Image ${ }^{8}$ shows her relieving herself standing at the men's urinals while she is talking to Michael Heseltine, one of the members of her government. In this scene, it is obvious that the objective was to represent her on the same footing as the male politicians who were still dominant on the late twentieth-century political stage. Besides, this representation can be considered as quite degrading since it aimed at ridiculing a British Prime Minister turned into an intruder into a male place of sociability. In this respect, she is presented as transgressing rules of decency. Furthermore, the scene suggests that she might have been cross-dressing as a woman and that, underneath her feminine clothes and makeup, a man was hiding.

What is more, the nickname "the Iron Lady", attributed to her in 1976 by the Soviet newspaper Red Star, encapsulated the association of feminine and masculine attributes in her characterisation. In this nickname, the supposedly distinguished and refined "Lady" is made out of "iron", a material famous for its strength and resistance. In order to celebrate Margaret Thatcher's handling of the military operations during the Falklands conflict, the Conservative politician Enoch Powell declared: "It [The Falkland's episode] shows that the substance under test consists of ferrous metal of the highest quality. It is of exceptional tensile strength, resistant to wear and tear, and may be used with advantage for all national purposes" (Blake and John 157). This quotation underlines her tenacity but it also suggests that she may have been more than a mere human being, or that she was undefinable. In this kind of representation, the fact that she was a woman is not considered as a fundamental aspect. Her masculinity does not seem to constitute something which is of any relevance either since what was 
scrutinised was her "substance". The use of the word "substance" indicates that her oddity had to be analysed in order to better understand her "strength" as a major political figure. When Enoch Powell uttered these words, he wanted to elaborate on the "Iron Lady" metaphor and revive it in a historical context which seemed appropriate and opportune. Indeed, the British victory in the Falklands War triggered expressions of patriotism everywhere in Britain and the Conservative Party enjoyed an overwhelming support from both the right-wing and left-wing traditional electorate at the 1983 general elections. It therefore caused a shift of the votes in favour of the Conservatives who won with a landslide majority.

Many of the parodies of Margaret Thatcher emphasized the complex nature of her identity and gender. Indeed, she was most often presented as a feminine woman, sometimes as a masculine woman, and at other times as a male figure. Yet, these complex parodies were frequently transcended by other forms of representation which befittingly highlighted her undefinable nature. Consequently, it seems important to explore the parodies presenting the Prime Minister as a sexless and genderless politician.

\section{Margaret Thatcher parodied as a sexless and genderless politician}

15 As Mary Douglas wrote in her work entitled Purity and Danger, published in 1969: "It is only by exaggerating the difference between within and without, above and below, male and female, with and against, that a semblance of order is created" (4). In the case of Margaret Thatcher, it seems that these exaggerations of differences blurred the distinctions between male and female.

Since Margaret Thatcher did not voluntarily present herself as a woman and did not insist on her femininity, Hugo Young suggested that we consider her as a "deeroticised" (305) politician, that is to say a woman who did not draw attention because of her sex. Her sex was also a crucial element in explaining why she became so famous and constantly attracted the attention of parodists. As a consequence, instead of considering her as someone who was "de-eroticised", we are going to develop the fact that she somehow transcended the dichotomy and was parodied as a sexless and genderless politician, that is to say one who could not be easily defined and categorized. When Hugo Young used the adjective "de-eroticised" to characterise Margaret Thatcher, he meant someone who did not have any sex appeal because her sex was not something people paid attention to. If Young did not use "de-sexualised", it was probably because such an expression would have had a degrading and absurd valence as it would mean that she was not a woman. Obviously, it is impossible to argue that she was not a woman but it is possible to claim that she did not put forward her femininity.

17 Generally speaking, many biographers and political commentators have presented Margaret Thatcher as an "outsider" to the Conservative Party of her time. In her biography of the "Iron Lady", Gillian Shephard lays particular emphasis on this characteristic. The use of the word "outsider" to portray her at the beginning of her political career, in the 1950s, enabled some parodists to underline the fact that she was completely unfamiliar with the political arena and the way British politics worked. In these parodies, her gender was often associated with her modest origins. Unlike most 
members of the Conservative Party, who were the descendants of aristocratic or, at least, upper-middle-class families, Margaret Thatcher came from a family of middleclass grocers from a small town called Grantham located in Lincolnshire. Cecil Parkinson, a former member of her government, explained that all of her ideas and values had one common origin in her childhood in Grantham, surrounded by her family: "It all goes back to Grantham. Grantham was the essence of Thatcherism" (Filby 3).

Throughout her political career, many people, politicians and journalists alike, criticised or satirised her for being a mysterious and fanciful character that did not fit into the mould of British politics. For instance, in the TV show Spitting Image, her puppet was presented singing a song called "The Grantham Anthem". In this extract, Margaret Thatcher is parodied as a materialistic woman who venerates money as if it were some sort of God. Besides, the sound of an organ playing constitutes a reference to her supposedly deep religious convictions. In her autobiographies, Margaret Thatcher insisted on her Methodist upbringing, especially when she wrote that she went to the Grantham church three times on Sundays and that her conversations with her father generally revolved around politics or religion (Thatcher 1995, 11). It seems that the parodists exploited this image of a devout politician who had based her political philosophy on religious grounds. For example, she often claimed that saving money in order to run a home decently and not expecting any financial help from the State or from anyone were values she had acquired in her childhood. In their turn, many parodists tended to exaggerate those features. Indeed, as Mike Freer, writes: "She is described, often disparagingly, as the grocer's daughter [...] who knew the value of thrift and of living within one's means, as if there was something wrong with that" (Dale 68).

19 Beyond the figure of the political "outsider", another kind of satire consisted in portraying Margaret Thatcher as a cruel and despotic creature who could sometimes appear either feminine or masculine, but who most of the time corresponded to a desexualised monster figure. When she was Edward Heath's Secretary of State for Education in 1971 and took the very unpopular decision to put an end to the delivery of milk for schoolchildren over the age of seven in order to make cuts in her ministry's budget, she was given the nickname "Thatcher, milk snatcher". ${ }^{9}$ This new way of considering the politician encouraged caricaturists like Gerard Scarfe who "loved to loathe Margaret Thatcher" 10 to produce many representations of the Prime Minister as a witch, as Count Dracula or as the Big Bad Wolf. These fictional characters prey on humans. Caricaturist Stanley Franklin was famous for being the originator of images representing Margaret Thatcher through the traits of cruel and sadistic characters or objects. For example, in an article of the Sun published on February $12^{\text {th }} 1975$, she was dehumanised and objectified as a torture instrument covered with blood. The only item which enabled readers to recognize her was her hat at the top of the drawing. The blood dripping along the machine was supposed to be that of her colleagues whom she would sacrifice if necessary. This caricature was entitled "Iron Maiden", a nickname which had preceded the "Iron Lady" pseudonym attributed to her by the Red Star in 1976. Besides, the "Iron Maiden" was the name of a torture instrument used in the Middle-Ages: it consisted in an iron cabinet with a spike-covered interior and two doors to lock people in. There is little humour about this satire, the aim of which was to denounce Margaret Thatcher's insensitivity by dehumanising her. She was also portrayed as someone who could dehumanise others because her first function was to 
kill them. This kind of representation, which amplified her cruel image, was also used by contemporary British artist Peter Kennard when he realised a photomontage entitled Thatcher Unmasked in 1986. ${ }^{11}$ On the picture, the Prime Minister shows her hidden face to the spectator who realises that a dreadful skull lies behind her mask.

When Margaret Thatcher was parodied as a genderless politician, the purpose was often to ridicule her or to emphasize her flaws. Some representations were quite harsh in this respect and it does not seem surprising that she often tried to respond to those parodies by elaborating new forms of self-presentation. The development and democratisation of television in the 1980s enabled her to enjoy an easier and more direct access to her fellow-citizens as more and more British people owned a television set and could watch politicians talk to them directly from the comfort of their living rooms. Moreover, in the late twentieth century, political communication techniques became more and more effective thanks to the cooperation of media advisers and spin doctors. As Arnaud Mercier argues, the 1980s were marked by the swift transition to new technologies which enabled political communication to develop readily (9). As Bernard Ingham, one of Margaret Thatcher's closest media advisers, declared, it was essential to use the different media efficiently for "the proliferation of broadcasting over the Thatcher years made for indigestion" (Ingham 344). Politics started to adopt the features of a show whose priority was entertainment. Some new expressions such as "politicotainment", "politertainment" and "entertaining politics" (Tsakona and Popa 9) have been created in order to emphasize the new nature of politics. Thanks to the theatricalization of power, politicians like Margaret Thatcher generated a form of political show while resorting to the hyperbolic dimension of theatre. She used parodies in her political performances and the British people, attracted by the staging of the show, would eventually provide her with their support. This is how Margaret Thatcher was able to retaliate against the parodies directed at her.

\section{Margaret Thatcher's retaliations}

21 As will be demonstrated in this final part, Margaret Thatcher responded to the parodies representing her: when the parodies were demeaning, she either tried to turn them into positive representations or to counter them. When they were positive, she took advantage of them and devised her own parodies exploiting the same ideas in order to enjoy a valorising reputation. Moreover, by parodying common attitudes and postures, she could appear as a charismatic figure who was able to attract her fellow citizens' attention. By trying to increase their charisma, politicians aim at expanding their authority and domination. Indeed, as Max Weber explained, "charismatic domination" corresponds to a situation in which the extraordinary features of an individual found his or her authority (212). Margaret Thatcher's charisma enabled her to adapt herself to new situations and to attacks by the media or by her political opponents. Depending on the contents and purposes of these attacks, she could reshape her political image in order to give new impetus to her self-presentation. By retaliating against the parodies which ridiculed or criticised her, Margaret Thatcher increased her power and redefined the features of her authority. In order to improve her political communication, she capitalised on the various representations which are going to be referred to in this section. 

came to symbolise her tenacity. With this aim in mind, she worked in partnership with political advisers who helped her to create parodies of attitudes expressing determination and inflexibility. For example, one of her closest advisers, Gordon Reece, ${ }^{12}$ devised the expression "the Lady's not for turning" which she employed at the annual Conservative Party Conference on October $16^{\text {th }} 1981$ in order to show that, unlike her predecessors and most Labour politicians of her time, she was not in favour of consensus politics. At the time when she uttered these words, even some members of her own government were urging her to change course and to adopt softer Keynesian economic policies. Indeed, her radical policies against inflation were creating unemployment and some of her poorest fellow citizens, who had already experienced hardships before 1979, were going through great economic and social distress. Especially those living in the inner cities of major British cities like Manchester, Liverpool or even London were left in a very fragile position. Nevertheless, through these words, Margaret Thatcher reaffirmed her status as a strong leader, who was convinced that, in order to curb inflation on the long run, it was necessary to make cuts in the welfare state in the short term. The expression also enabled her to refer to her "Iron Lady" nickname in a compact and effective slogan which was both catchy and straight to the point. It was particularly important at a time when the Conservative Party Conference could be broadcast on the television to devise slogans which could attract people's attention and be easily memorised. The expression quickly became a symbol of Thatcherism and its ideals. It is interesting to note that it originated from a 1948 play by Christopher Fry entitled The Lady's Not for Burning. The play is set in the Middle-Ages and its main character is a woman accused of practicing witchcraft.

When, on January $24^{\text {th }} 1976$, the Soviet propaganda newspaper Red Star-Krasnaya Zvezda in Russian-baptised Margaret Thatcher the "Iron Lady", its first objective was to criticise her for her inflexibility and lack of diplomacy. The article was published the year after she became leader of the Conservative Party with a strongly anti-communist agenda. The nickname thus constituted a Soviet retaliation against her initial attack. Right after the Red Star was issued and the "Iron Lady" nickname was relayed by the British press, she herself redefined the expression in order to give it a positive meaning. This retaliation occurred in a speech she delivered on January $31^{\text {st }} 1976$ in Southgate:

I stand before you tonight in my Red Star chiffon evening gown, my face softly made up and my fair hair gently waved, the Iron Lady of the Western world. A Cold War warrior... Yes, I am an iron lady, after all it wasn't a bad thing to be an iron duke; yes, if that's how they wish to interpret my defence of values and freedoms fundamental to our way of life. (Moore 2014, 333)

The reference to the "iron duke" points to the Duke of Wellington, a protector of the British nation and of its values. Thus, with this clear explanation, Margaret Thatcher managed to update the definition of the "Iron Lady" expression by giving it her own spin. The Soviet newspaper's formula constituted an attack against her, which she turned into something positive by parodying it thanks to her use of irony. During her speech, she made a short break after each sentence in order to give it more clout and so as to leave some time for the audience to laugh and applaud. The apex of laughter was reached when she declared that she was "the Iron Lady of the Western World". She was then wearing a red dress-her "Red Star chiffon evening gown"-and red lipstick, which constituted a physical reference to the name of the newspaper and, by extension, to the

Polysèmes, 23 | 2020 
symbolic colour of communism. ${ }^{13}$ She thus reclaimed the red colour and made it her own symbol of power and showed that she could be as intimidating and threatening as the Soviet journalists had been, if not more. Although she actively participated in the writing of most of the speeches she delivered, Margaret Thatcher could count on a number of communication advisers to help her build up her rhetoric. For example, her media adviser Gordon Reece, who started working with her during the 1975 campaign for the leadership of the Conservative Party, encouraged her to entrust speechwriting activities to Ronald Millar, a famous British stage director and playwright. The aim was to put the party leader in a position of controlling the parodying process and turn into her own self-parodist.

When the Falklands War broke out and Margaret Thatcher decided to send a British task force in order to seize back the islands which had been invaded by an Argentine junta led by General Leopoldo Galtieri, she was at first rather uncertain concerning Great Britain's final success and the demise of the Argentine junta. Yet, by the end of the conflict, when the Royal Navy began to override the Argentinian invaders, she started to show an image of determination and conviction. That is why it is possible to argue that she parodied the posture of the Churchillian war hero: she wanted to be perceived as a devoted protector of the British nation. In 1975, she declared: "You will understand, I know, the humility I feel at following in the footsteps of great men like [...] Winston Churchill [...] who raised the name of Britain to supreme heights". ${ }^{14}$ As Simon Jenkins explains, "Thatcher exploited the war to boost her personal standing" (77). She used this event to improve her own reputation while presenting herself as a strong leader ready to reap the rewards of her success. Each war constitutes an opening to create a saga composed of violence, death, glory and defeat. The British citizens were given the opportunity to become patriotic spectators, physically passive but mentally involved in the conflict. This strategy was quite effective as, during the war, support for Margaret Thatcher's government grew from sixty per cent of the British population to seventy six percent (Moore 2013, 705) and the victory in the Falklands enabled the Conservative Party to be re-elected at the 1983 early general elections.

In order to soften her image of merciless warrior and to appear closer to the British people, Margaret Thatcher also resorted to the parody of the middle-class housewife. For instance, during her campaign for the 1979 general elections, she followed the advice of Gordon Reece who told her to go shopping in the King's Road in front of the journalists' cameras (Campbell 2000, 430) so that British people could see her in their favourite newspaper or watch her on TV. The main objective of this communication strategy was for her fellow citizens to perceive her as an ordinary woman whose priorities were her domestic chores and the good running of her home. In The Daily Telegraph from April $25^{\text {th }}$ 1979, people could see her holding two shopping bags and explaining that the spending power had fallen for all the preceding five years of Labour government, that is to say from the demise of the Conservatives in 1974 until 1979 (Campbell 2000, 430). She acted out the posture of the housewife and used it as an instrument for the sake of her political propaganda.

27 Even much earlier, in the 1960s, when Margaret Thatcher and her husband Denis moved into a big house called Dormers in Farnborough, she started gardening and, as a Member of Parliament for the Finchley constituency, invited journalists to take pictures of her in her garden. The aim of this dramatization was to build the image of a woman who enjoyed maintaining order from the inside of her comfortable house to 
every corner of her garden. Thanks to this representation, she could promote ideas such as law and order, cleanliness, dignity and self-responsibility. Even though she must have had a very busy schedule because of her professional occupation and ambitions, she told The Daily Mirror on February $3^{\text {rd }}$ 1975: "I am a very ordinary person who leads a very normal life. I enjoy it-seeing that the family have a good breakfast. And shopping keeps me in touch" (Campbell 2000, 296). Such a statement implies that she wanted to be seen as a simple person, comparable to any British housewife, and as a genuinely Conservative woman who was keen on defending traditions. These words also emphasize her role as a mother, a type of representation which was recurrent in her speeches and postures.

As a mother of twins, Margaret Thatcher could easily claim to embody the archetypal figure of mother of the nation. In her autobiography entitled The Downing Street Years, she insists on the importance of the family unit while referring to one of her main objectives: preserving the model of "the traditional family" (Thatcher 1993, 628). According to her, maintaining such traditional values served as a barrier against immorality and criminality. She considered that the rise of criminality and social disorientation was partly due to the fact that there were more and more single mothers taking care of their children on their own. In her autobiography, she explained that "boys who lack the guidance of a father are more likely to suffer social problems of all kinds" (Thatcher 1993, 629). She wanted to present herself as a perfect mother so that her own household could be perceived as a model by all her fellow citizens. Besides, when she was Edward Heath's Secretary of State for Education in the early 1970s, she adopted the appearance of a reassuring politician who knew perfectly well what she was talking about. Indeed, being a mother in her private life enabled her to be perceived as someone who was highly legitimate in these functions. The image of the perfect housewife and mother was a way of responding to the attacks of the "Stop Thatcher"15 campaign, which claimed that she did not have any consideration for the members of the working class and only focused on the wellbeing of the country's elite. Presenting herself as the nation's mother therefore gave her the advantage of being at the same time above the British people and part of one great family. It also allowed her to be associated with the values of softness and care.

\section{Conclusion}

This article has shown that many parodies concerning Margaret Thatcher have focused on either her feminine or masculine appearances. These two aspects were often contrasted in order to show that the two gender categories are exclusive. Yet, some studies of the notion of gender which took place in the period when Margaret Thatcher was in power had the ambition of showing that the division between femininity and masculinity is not as clear-cut as it seems to be. For instance, Judith Butler argued that "no one is born with a gender-gender is always acquired" (151). Several parodists represented the British politician as someone who transcended the sex and gender distinctions. Instead of insisting on the idea of a clear contrast between femininity and masculinity, these parodists tended to either create generic confusion by mixing the two genders or to represent her as a sexless politician without taking her womanhood into account. Besides, some of the parodies also showed her as an inhuman creature, thus caricaturing her as a parodied object which was above or below humanity. Indeed, 
most of the time, the parodies were either eulogistic or extremely negative. Finally, it has been demonstrated that Margaret Thatcher used her own femininity and masculinity to devise retaliations against the parodies which aimed at ridiculing or criticising her. She also took advantage of certain positive representations by the media and exaggerated them so as to fully benefit from their supportive dimension. She thus insisted on the fact that she could become an archetypal representation of both authority and care, depending on the contexts in which these images could benefit her reputation. It thus appears that she took advantage of some of the parodies produced to consolidate her public image. Even though these parodies aimed at giving a negative inflexion to her political image, her retaliations kept on strengthening her authority and reputation over time.

\section{BIBLIOGRAPHY}

Blake, Stephen and Andrew John. Iron Lady: The Margaret Thatcher Years (2003). London: Michael O’Mara Books Limited, 2012.

Butler, Judith. Gender Trouble (1990). New York: Routledge, 2007.

Campbell, John. Margaret Thatcher. Volume One: The Grocer's Daughter. London: Jonathan Cape, 2000. Campbell, John. Margaret Thatcher. Volume Two: The Iron Lady. London: Jonathan Cape, 2003.

Dale, Iain (ed.). Memories of Margaret Thatcher: A Portrait, by Those Who Knew Her Best. London: Biteback Publishing Ltd, 2013.

Douglas, Mary. Purity and Danger: An Analysis of Concepts of Pollution and Taboo. London: Routledge, 1969.

Evans, Eric. Thatcher and Thatcherism (1997). New York: Routledge, 2004.

Filby, Eliza. God \& Mrs. Thatcher: The Battle for Britain's Soul. London: Biteback Publishing Ltd, 2015. Ingham, Bernard. Kill the Messenger. London: Hammersmith, 1991.

Jenkins, Simon. Thatcher and Sons: A Revolution in Three Acts (2006). London: Penguin Books, 2007.

Mercier, Arnaud. La Communication politique. Paris: CNRS Éditions, 2017.

Minois, Georges. Histoire du rire et de la dérision. Paris: Fayard, 2000.

Moore, Charles. Margaret Thatcher, The Authorized Biography: Volume One (2013). London: Penguin Books, 2014.

Moore, Charles. Margaret Thatcher: The Authorized Biography: Volume Two. London: Penguin Books, 2015.

Shephard, Gillian. The Real Iron Lady: Working with Margaret Thatcher. London: Biteback Publishing Ltd, 2013.

Swedberg, Richard. The Max Weber Dictionary: Key Words and Central Concepts. Stanford: SUP, 2005.

Thatcher, Margaret. The Downing Street Years. London: Harper Collins, 1993. 
Thatcher, Margaret. The Path to Power. London: Harper Collins, 1995.

Tsakona, Villy and Diana Elena Popa (eds.). Studies in Political Humour. Philadelphia: John Benjamins, 2011.

Weber, Max. Economy and Society: An Outline of Interpretive Sociology (1922). Berkeley: U of California P, 1978.

Young, Hugo. One of Us: A Biography of Margaret Thatcher. London: MacMillan, 1989.

http://www.margaretthatcher.org (last accessed 12 April 2020)

https://www.npg.org.uk (last accessed 12 April 2020)

https://www.theglobeandmail.com (last accessed 12 April 2020)

http://banmarchive.org.uk (last accessed 12 April 2020)

https://www.youtube.com (last accessed 12 April 2020)

https://www.economicshelp.org/macroeconomics/economic-growth/uk-recession-1981/ (last accessed 12 April 2020)

http://www.peterkennard.com/thatcherism (last accessed 12 April 2020)

https://www.bbc.com/news/entertainment-arts-22076837 (last accessed 12 April 2020)

\section{NOTES}

1. https://www.npg.org.uk/collections/search/portrait/mw251471/Gone-with-the-WindRonald-Reagan-Margaret-Thatcher, last accessed 12 April 2020.

2. https://www.economicshelp.org/macroeconomics/economic-growth/uk-recession-1981/, last accessed 12 April 2020.

3. https://www.economicshelp.org/macroeconomics/economic-growth/uk-recession-1981/, last accessed 12 April 2020.

4. https://www.youtube.com/watch?v=jINZBOxdja8, last accessed 12 April 2020.

5. reported from a private interview given by François Mitterrand: the exact source remains uncertain.

6. https://www.theglobeandmail.com/community/inside-the-globe/thatcher-caligulamonroewait-did-i-hear-that-right-the-dangers-of-misquoting/article4101423/, last accessed 12 April 2020.

7. http://banmarchive.org.uk/collections/mt/pdf/83_07_07.pdf, last accessed 12 April 2020.

8. https://www.youtube.com/watch?v=_rMnv6sZVow, 7'10", last accessed 12 April 2020.

9. The expression comes from Labour education spokesman Edward Short when, in 1971, he declared that depriving children from milk was "the meanest and most unworthy thing" he had seen in 20 years.

10. https://www.bbc.com/news/entertainment-arts-22076837, last accessed 12 April 2020.

11. http://www.peterkennard.com/thatcherism, last accessed 12 April 2020.

12. Gordon Reece was Margaret Thatcher's political strategist when she applied for the leadership of the Conservative party in 1975. After her victory, he kept on working for her and played a prominent role in the 1979 general election campaign.

13. https://www.youtube.com/watch?v=oAgM6YHioxI, last accessed 12 April 2020.

14. Margaret Thatcher's speech to the Conservative Party Conference, October 10, 1975, https:// www.margaretthatcher.org/document/102777, last accessed 12 April 2020. 
15. The "Stop Thatcher" campaign was mounted in 1975 by members of the Conservative party who still supported the ex-Prime Minister Edward Heath and were opposed to Margaret Thatcher taking the leadership of the party.

\section{ABSTRACTS}

This article focuses on various representations of Margaret Thatcher, when she was British Prime Minister between 1979 and 1990. It takes into account the different parodies produced about her as well as her own retaliations against those parodies by constantly updating her political image. It thus argues that Margaret Thatcher was both the object of various parodies elaborated by the media or by her political entourage and a politician who devised her own responses in order to improve her self-presentation. Besides, this study offers an outlook on the complex roles played by gender in the parodies while insisting on both their reactivation of realities and their creative dimension. For instance, this article emphasises the fact that most parodies concerning Margaret Thatcher focused either on her feminine and masculine appearances or on her representations as a sexless and genderless politician. The effects of these parodies on public opinion are also briefly commented on. For example, some of them created a satirical effect derived from parodic humour while others were based on cruel representations which prompted public hostility or compassion. The final objective is to assess the power of parodies on the politician's reputation while analysing how Margaret Thatcher retaliated against her negative portrayals. Moreover, her self-glorification through the insistence on valorising representations enabled her to improve or consolidate her political image and reputation.

Cet article s'intéresse à différentes représentations de Margaret Thatcher lorsqu'elle était Premier ministre du Royaume-Uni de 1979 à 1990. Il explore les nombreuses façons dont elle fut parodiée ainsi que ses propres réactions, qui reflètent son intention de moduler constamment son image politique. Il est donc considéré que Margaret Thatcher était à la fois l'objet de différentes représentations parodiques élaborées par les médias ainsi que par son entourage politique et une femme politique qui façonnait ses propres réactions afin d'améliorer son image. Par ailleurs, cette étude offre un éclairage sur la complexité des rôles joués par le genre dans les parodies. Leur capacité à réactiver des réalités ou à faire preuve de créativité est mise en évidence. Cet article met ainsi l'accent sur le fait que la plupart des parodies concernant Margaret Thatcher se concentraient soit sur ses aspects féminins et masculins, soit sur sa représentation en femme politique dépourvue de sexe et de genre. Les effets de ces parodies sur l'opinion publique sont également brièvement abordés. Par exemple, certaines d'entre elles provoquaient un effet satirique dû à l'humour parodique, alors que d'autres se fondaient sur des représentations cruelles qui encourageaient l'hostilité ou la compassion de l'opinion publique. L'objectif final consiste à évaluer le pouvoir des parodies sur la réputation de la femme politique tout en analysant les moyens qu'elle avait de réagir face aux représentations négatives. Se servir de représentations valorisantes pour élaborer sa propre glorification lui permettait en outre d'améliorer ou de consolider son image politique et sa réputation. 


\section{INDEX}

Keywords: United Kingdom, Conservative Party, Margaret Thatcher, political image, representation, media, satire, femininity, masculinity

Mots-clés: Royaume-Uni, parti conservateur, Margaret Thatcher, image politique, représentation, médias, parodie, féminité, masculinité

\section{AUTHOR}

\section{YVES GOLDER}

Yves Golder holds a PhD in British History, specializing in $20^{\text {th }}-21^{\text {st }}$ centuries British politics, society and media. He is a member of the SEARCH research center from the University of Strasbourg. His thesis, which he defended on April $5^{\text {th }} 2019$, focuses on the construction of Margaret Thatcher's political image from 1950 to 1990. It was supervised by Professors Christian Auer and Hélène Ibata. His main areas of interest involve the British Conservative Party and media representations, but also other political and contemporary issues such as the Brexit referendum and its ensuing negotiations or the way the Conservative Party has been dealing with European issues since the Thatcher era. His publications reflect his threefold interest in Thatcherism, its representations and its aftermath. Besides, Yves Golder is teaching fellow at the faculty of law, political sciences and management of the University of Strasbourg. 